\title{
Learning And Teaching Styles In Management Education: Identifying, Analyzing, And Facilitating
}

Michael J. Provitera, (Email: mprovitera@barry.edu), Barry University Esin Esendal, (Email: dean@amcollege.edu), University of Virginia

\begin{abstract}
Drawing on the learning theory of the Felder-Silverman model (2002), and the work of A.F. Grasha, this paper provides a brief review of teaching and learning styles used in management education. Professors, like students, demonstrate a number of learning styles and a professor has some responsibility to organize and present a course to satisfy students' varied learning styles. After a brief review of the literature this paper suggests ways to assess the teaching and learning styles of management educators and students.
\end{abstract}

Keywords: Teaching Style; Learning Style; Management Education; Higher Education

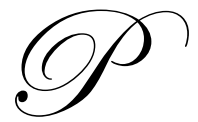

professor overcome this mismatch?

rofessors, like students, demonstrate a number of learning styles and a professor has some responsibility to organize and present a course to satisfy students' varied approaches. Is there a mismatch between a professor's way of teaching and the way students learn? If so, how should the

This paper presents the work of two authors offering surveys to assess professors' teaching style levels and students' learning style levels, with an eye toward how these skills transfer into the workplace. The paper begins with an introduction to teaching and learning styles, followed by teaching styles assessment and review, learning styles assessment and review, and discussion. The paper makes its main points in the Conclusion.

While management educators are experts in their own field, they may lack a complete theoretical understanding of teaching and learning styles. This theoretical understanding could help them analyze and improve the teaching and learning experience. The paper suggests implications for further research in this area.

Management scholars have criticized learning styles theory, but the concept is still widely used as a viable means of determining one's learning style. Freedman and Stumpf (1980) argued that supporting evidence of learning style surveys comes from an unreliable instrument designed so that its results spuriously corroborate the theory. However, some management scholars used the learning style surveys to provide pedagogical advice (McMullen and Cahoon, 1979; Randolph and Posner, 1979). For instance, McMullen and Cahoon advised professors that "students will be taught to be more discriminating in their social learning, both in choosing what to learn and in clarifying what has been learned." Prior research shows that teaching and learning style mismatches may enhance the learning process (De Vita, 2001). Such a mismatch may give the student an opportunity to expand the range of his or her learning style to fit what the teacher is doing.

According to Salaman and Butler (1990, p. 185) "What is valued is certainty, tied to prescription." In a study of business students, the Index of Learning Styles Questionnaire by Felder and Soloman has been routinely employed for some years as a component of management development courses in business schools (Van Zwanenberg, Wilkinson, and Anderson, 2000). 
Professors employ their own teaching styles, and most educators are likely to feel that the styles they use are appropriate to their needs. However, management educators still raise the question: How much should a teacher adapt to fit the learning styles of students (Thompson, 1997, p. 1)? While teaching styles may differ, students may reach the same learning levels, but would their experience be more enjoyable and engaging with different teaching methods such as the case method and experiential learning (Kolb, Boyatsis, and Mainamelis, 2002; Anoloui, 1995; Buch and Bartley, 2002)?

Hall and Moseley (2005) describe a wide variety of learning styles. Jenson (1987) argues that students' individual personality types are associated with four-out-of-eight combinations of the Myers-Briggs Type Indicator preferences (learning styles) (1956). The Myers-Briggs Type Indicator (MBTI) personality inventory is grounded in C. G. Jung's theory of psychological types and is first presented in Quenk's "Psychological Types" (2000). Despite all of this research on learning styles, teaching styles have been neglected, leaving a limited amount of data in this area.

Laight (2004) found that teachers must address all types of learning styles if students are to grasp the material. De Vita (2001) asserted that business professors must move toward a multi-style teaching approach if all students are to reach their potential in the multicultural classroom. However, understanding both teaching and learning styles is only a first step.

This paper will address how teaching styles and learning styles can be used to enhance management education. While there are a number of methods available, this paper concentrates on two. One consists of assessing both teaching and learning styles, while the other focuses on the learning styles. The more compatible teaching style is with learning style, the more likely it is that there will be a positive learning experience (Ament, 1986).

Mumford (1983, p. 1) contends that:

"Management educators should research the learning process and help improve learning by providing a learning process tailored to individual needs. The learning process should account for individual learning styles. Educators also must make more effective use of student opportunities to learn while they are preparing the lecture plan. Knowledge must be made more applicable to real situations. The learning process itself must be researched more thoroughly to determine how things are learned. In addition, educators should be concerned about the effectiveness of the learning process as well as the effectiveness of managers who have undergone management education. By ensuring that the learning process is effective and based on solving real problems, the manager has a better chance of learning continuously, even after the coursework is completed."

This brings up a pertinent topic in business education: business schools have not addressed critical curriculum weaknesses in such areas as communication, leadership, and relationship management (Doria, Rozanski \& Cohen, 2003). Greiner, Bhambri and Cummings (2003) found that this neglect results in students graduating with strong conceptual expertise but weak application skills. Management educators know enough about their subject, but they may not know how to match teaching and learning styles. The next section presents two methods of identifying and analyzing teaching and learning styles.

\section{TEACHING AND LEARNING STYLES}

Grasha (1994) found that teaching is a matter of style. He identified the five styles of teaching as expert, formal authority, personal model, facilitator, and delegator. Each style, along with its advantages and disadvantages is defined by Grasha (1996, p. 154; Grasha and Reichmann, 2006). Management educators can determine their teaching style by taking the survey at the website (http://longleaf.net/teachingstyle.html). The results of this survey reveal educators' teaching preferences.

Learning styles addressed in this paper are based on Felder's identification of learning and teaching styles in the classroom (1993), and Soloman's inventory of learning styles (1992). These scholars offer their research as a tool for both educators and students. The research shows that learners can be active, reflective, sensing, intuitive, 
visual, verbal, sequential, and global. Each style is defined by Felder and Soloman's index of learning styles (2006a). Teachers can ask their students to determine their individual learning styles by having them go to the website (http://www.engr.ncsu.edu/learningstyles/ilsweb.html) to take the survey. The results of the survey are automatically analyzed providing students with their preferred learning styles. Also, Felder and Soloman provide an information sheet suggesting strengths and potential areas of difficulty (2006b).

\section{A Summary Of Grasha's Teaching Styles}

The following passages summarize definitions of teaching styles in the work of

$$
\text { A.F. Grasha (1996): }
$$

Expert: Possesses knowledge and expertise that students need. Expert teaching style strives to maintain status as an expert among students by displaying detailed knowledge. The professor-as-expert attempts to challenge students to enhance their competence. The expert concentrates on transmitting information, and requires that students be prepared to learn and use that information. The expert's information, knowledge, and skills are the combined advantage of this teaching style. The disadvantage is that, if overused, the display of knowledge may intimidate less experienced students. Also, the display of knowledge and skills may not always reveal their underpinnings.

Formal Authority: Possesses status among students because of knowledge, and role as a faculty member. In this style professors provide positive and negative feedback. The professor establishes learning goals and expectations and rules of conduct, providing students with a learning structure. Students concentrate on correct, acceptable, and standard methods. The advantage is that the focus is on clear expectations and acceptable methods, while the disadvantage is that a strong investment in this style can lead to rigid, standardized, and less flexible ways of managing students and their concerns.

Personal Model: Believes in teaching by personal example. This professor establishes a prototype for thinking and behavior, then oversees, guides, and directs by showing how to do things. A Personal Model teacher also encourages students to observe, then emulate the instructor's approach. The advantage is an emphasis on direct observation and emulation of a role model. The disadvantage is that some professors may believe that their approach is the best way, leading some students to feel inadequate if they cannot live up to the expectations and standards of the method they see.

Facilitator: Emphasizes the personal nature of teacher-student interactions. The professor guides and directs students by asking questions, exploring options, and suggesting alternatives. The professor encourages students to develop criteria to make informed choices. The professor concentrates on the overall classroom goal of developing the capacity for independent action, initiative, and responsibility, while providing students with as much support and encouragement as possible. The advantage is the personal flexibility provided by a professor's focus on students' needs and goals. This allows the student to explore options and alternative courses of action. The disadvantage is that this style can be time-consuming.

Delegator: This professor develops students' capacity to function in an autonomous fashion. This educator encourages students to work on projects independently or as part of autonomous teams. He or she is available upon request as a resource person. This approach has the advantage of helping students perceive themselves as independent learners, but it may cause professors to misread student's readiness for independent work. Some students may become anxious when given autonomy.

The few other current studies focus on teaching approaches, such as teachers as managers (Anoloui, 1995), training delivery techniques (Buch and Bartley, 2002), and experiential learning theory (Kolb, Boyatsis, and Mainamelis 2002). With the current shortage of literature on teaching styles, Grasha's definitions are one of the few useful tools professors have. Using the definitions as a guide, educators may see their own teaching styles, and identify their strengths and weaknesses. 
Grasha's paper is a first step in exploring teaching styles for management professors. It lays a foundation for more empirical research in this area. The next section will explore learning styles and how they address management education.

\section{A Summary Of Felder And Soloman's Learning Styles}

Active and Reflective Learners: Active learners retain and understand information best by doing something with it. They may discuss it, apply it or explain it to others. Reflective learners prefer to think about it first. Felder and Soloman argue that a balance of the two is desirable. If you always act before reflecting you can jump into things prematurely and get into trouble; if you spend too much time reflecting you may never get anything done.

Sensing and Intuitive Learners: Sensing learners like facts while intuitive learners often prefer to discover possibilities and relationships. An effective learner and problem solver does both. If you overemphasize intuition, you may miss important details or make careless mistakes in calculations or hands-on work, while if you overemphasize sensing you may rely too much on memorization and familiar methods and lack understanding and innovation.

Visual And Verbal Learners: Visual learners remember what they see. They prefer pictures, diagrams, flow charts, timelines, films, and demonstrations. Verbal learners get more from words. They prefer to read or hear verbal explanations. Everyone learns more when information is presented both visually and verbally. Felder and Soloman contend that most people are visual and most students do not absorb as much from verbal sources as they would if a more visual presentation were used in the classroom. However, good learners can process information either way.

Sequential And Global Learners: Sequential learners see things in linear steps, with each step following logically from the previous one. Global learners take big leaps, absorbing material almost randomly, seemingly without connection, then suddenly recognizing information in its larger context. While sequential learners may not fully understand the whole, they can put the pieces to work because they see the logical connections. Global learners often have serious difficulties until they see the big picture. Though sequential learners may know many specific aspects of a subject, they may have trouble putting these aspects together, or relating them to different subjects.

Felder and Soloman contend that each of these four models presents a balance, and a student can learn best by using both processes. When professors recognize these learning models they can adapt their approaches accordingly.

This summary of learning styles encourages further exploration for both the professor and student. The first dimension - sensing versus intuitive - distinguishes between learners who prefer the concrete (sensors), and those who prefer the conceptual (intuitors). The second dimension distinguishes between learners who prefer pictures, diagrams, or charts (visuals) and learners who prefer written or spoken explanations (verbals). The third-active versus reflective - distinguishes between learners who prefer working things out, often in groups (actives), and those who prefer thinking things through, usually alone (reflectives). Finally, sequential-versus-global divides those who prefer linear, orderly learning (sequentials) from the ones who are more comfortable with holistic approaches and learning in large leaps (globals) (Bacon, 2004). Professors and students may both benefit from understanding these learning styles.

The next section provides a brief discussion of teaching and learning styles and how they may apply to management education.

\section{DISCUSSION}

A teaching style may appear to be a one-way communication between the professor and the student, while learning styles are more obvious in their involvement of both professor and student. In truth teaching and learning styles are two ends of a dynamic continuum, elusive because they are always changing. 
Styles of teaching and learning may contradict one another. Experts and delegators may present too many details for the global or visual learner. A personal teaching style may not offer an intuitive learner enough chance to explore and discover. Professors should design programs in order to achieve goal congruity: where teaching meets students' needs while covering the overall objectives of the course (Macfarlane and Lomas, 1995). A professor and students will achieve better goal congruity if they understand learning styles as early as possible.

Each classroom offers a diverse pool of learners. A teacher must address both the individual and the group. McCombs (1991) argues that support is overwhelmingly on the side of practices that honor the perspectives of the individual learner and his or her needs for competence, control, and belonging. Long-lasting meaningful learning (learning that can be used in the workplace) is more likely to occur when students become interested in the subjectmatter for its own sake (Vroom, 1964), rather than to comply with an external demand (Boud, 1990, Kinman and Kinman, 2001).

Instructors' and students' can better define their learning styles by taking a free survey at the beginning of the semester or school year. When students can identify and explore their own learning styles, they can also gain awareness of how they might approach learning. They realize they have some control (Spicer, 2004). Felder and Soloman offer this survey free in order to compile more research data. Other copyrighted instruments for defining learning styles are available for a fee.

The premier researcher in the area of learning styles is Kolb. Kolb's experiential learning model (1984) has been established through application. He bases his model on Jung's concept of types and styles (1976) which states that the individual develops by using higher level integration and expression of nondominant modes of dealing with the world (Loo, 2002). Furthermore, Kolb's Learning Style Inventory describes how we learn and apply ideas in day-to-day situations.

Felder and Silverman (2002) extend Kolb's pioneering research model by making their research available and accessible to professors and students. While Kolb's initial research is the most comprehensive empirical research available, Felder presents a website where one can learn about recent research on teaching and learning styles.

Management educators should accept that each student is a unique and valued member of the university and society. Each student has the right to expect a valuable education in management with real-world applications. As Hanno observes students expect three things from their instructors: they want to learn, they want preparation for life beyond college, and they want help in realizing their potential $(1999$, p. 323). In short they want professors who develop their strengths and reduce their weaknesses.

Felder's Index of Learning Styles has not gone without criticism. Bacon found that the learning style measurements freely available on the internet were unreliable, and were of little help in student learning. Mumford and Honey (1992) advise against using the learning style questionnaire because: 1) learning style preferences can change, 2) the self perceptions required in the questionnaire have limited accuracy, 3) the questionnaire is repetitious, and 4) when someone disagrees with the results they get limited direction. This criticism doesn't prove the questionnaire is useless, it only shows that more research is needed to determine how useful it is.

Future research should improve the methods of measuring the effectiveness of teaching and learning styles in management education. Also, reliability studies should be designed to judge how well instruments measure learning and teaching styles. These studies should measure how consistently outcomes reinforce prior research, and they should explore new disciplines such as management education. Finally, we must create empirical models aimed at improving the classroom environment for learning. It would make sense to devise an integrated model that not only identifies the instructor's teaching style and the student's learning style, but also shows how these styles can work together.

The online learning environment gives us a huge platform for research. With the proliferation of online learning classrooms are becoming cyber cafes. In this environment business educators must coach, facilitate, grade, 
and demonstrate their expertise from a distance. In some cases, business professors do not contribute to the design of the course itself, and act as subject-matter experts only. The course designers define the course structure from the syllabus through textbook selection, and even delineating the assignments. Empirical research will show whether learning and teaching styles affect business education when the face-to-face component does not exist.

Since management education spans many areas from Organizational Behavior to Human Resources and beyond, teaching and learning cannot be taught in the same manner. Dialogue about methods will always remain at the crux of effective teaching and learning. Talented professors come in different sizes, shapes, ages, and genders, and they will not all teach in the same manner. However, while teaching methods may vary, they all aim to stimulate students' enthusiasm, and the methods do not alter what must be taught. The dynamic between teaching and learning styles may change as both the professor and student progress. This change should be measured at various stages in the educational process. The idea of development of one's craft through experimentation applies to all areas of higher education. This paper offers one method for that experimentation. This method has been used in management education, and in other collegiate disciplines.

\section{CONCLUSION}

Like any educators, management professors take different approaches to teaching. Some are great story tellers, others analyze case studies. There are the spellbinding lecturers, and experts in interactive learning. Can one teacher be expected to morph from one to the other? Or is such an attempt more likely to reduce a teacher's effectiveness in the classroom? In management education should discussion learning be the preferred method of teaching or should it be no more than a component?

A professor choosing between the roles of facilitator or lecturer, might find that in general the former appears to be a better technique. However, this also might be determined by the student's prior knowledge of the subject. The more knowledge the student has the less the need for broad-based classroom lectures.

If radical change is preferable to enhance management education, the change must be continuous and progressive. Each teacher and each student must evaluate situations as they arise. Truly effective teaching styles will be based on the individual strengths and weaknesses of each instructor, coupled with the personal learning style of each student.

Up until now knowledge of learning and teaching styles has not been a pre-requisite to teaching management. This paper is targeted to those management educators that may not be aware of the research in these areas. Simply providing this information to management educators may help them improve their effectiveness.

In Whetton and Clark (1996) the authors argue first, that students must clearly understand guidelines and principles for practical application. Management educators must target a small set of relevant principles (behavioral guidelines). Second, the instructor must emphasize practice sessions with personalized objectives. The more personalized the objectives, the more relevant the student's experience. Students must understand specific skills they need for improvement. Management educators must understand which combination of principles and practice will help each student learn. These educators should incorporate these principles and behavioral guidelines while focusing on novel ways to improve their teaching. The practical applications become clear when students see that management, once learned, can enhance one's life both professionally and personally.

Assessing, measuring, and incorporating teaching and learning styles into the class discussion can improve learning in any field, including management. When managers see the implications of their own and others' learning styles, this understanding will help them build better working relationships between individuals, and create functioning teams (Hayes and Allinson, 1994). Furthermore, Kolb suggests that there might be value in lecturers and students explicitly sharing their respective theories of learning. Management students may gain insight into why things are taught the way they are, and see adjustments that improve their approach to learning. Educators will be able to identify the variety of learning styles present in their classes, and modify their approaches to accommodate these differences. 
Turner (1999) contends that a student needs to develop a learning style to achieve learning objectives. Learning can be triggered by personal identity, prior learning, experience, external factors, and individual perceptions about learning. Identifying and exploring these elements can accentuate classroom diversity, encouraging originality in students' approaches to business concepts (Wynd and Bozman, 1996). When individuals understand their own learning this presents a great opportunity to discuss how they learn. This helps them put learning into practice (Mumford, 1995).

While both common sense and research suggest that management educators are likely to teach in ways consistent with their own learning styles (Lyons, 1984; Lehto, 1989), it is also common sense to realize that management educators cannot be "all things to all people" (Thompson, 1997). However, educators should never cease in their efforts to develop themselves and their skills to meet the many diverse needs of their students. The traditional teacher-centered classroom was designed for auditory and visual learners, but today's classrooms are more student-centered. Today's classroom is far more focused on hands-on and cooperative learning experience (Hill, 2005).

The twofold premise of this paper is that educators must take the first step in creating awareness of teaching and learning styles, and that this awareness, on their part and on the part of their students, will improve management education. As one progresses from pedagogy to andragogy, from teacher-centered to learner-centered, and from rote learning to active learning, it becomes clear that a the use of a variety of teaching techniques will provide the most success in appealing to the broadest range of student learning styles.

\section{REFERENCES}

1. Anoloui, F. (1995). Teachers as managers: An exploration into teaching styles, The International Journal of Education Management Bradford. 9 (5): 16-20.

2. Ament, L. 1986. Focus on the Adult Learner. Winnipeg, Manitoba: University of Manitoba Press.

3. Bacon, D. R. 2004. An examination of two learning style measures and their association with business learning, Journal of Education for Business. 79(4): 205-208.

4. Boud, D. 1990. Assessment and the promotion of academic values. Studies in Higher Education. 15(1): 101-11.

5. Buch, K. and Bartley, S. (2002). Learning style and training delivery mode preference, Journal of Workplace Learning, 14 (1/2): 5-10.

6. De Vita, G. 2001. Learning styles, culture and inclusive instruction in the multicultural classroom: A business and management perspective. Innovations in Education and Teaching International. 38(2): 165174.

7. Doria, J., Rozanski, H., \& Cohen, E. (2003). What business really needs from B-schools? Strategy + Business, 39-45.

8. Farwell, T. (2002).Visual, auditory, kinesthetic: Which is your child? Family Education.com.

9. Felder, R. 1993. Reaching the second tier: Learning and teaching styles in college science education. Journal of College Science Teaching. 23(5): 286-290.

10. Felder, R., and Silverman, L. K. (2002). Learning and Teaching Styles in Engineering Education, Engr. Education, 78(7), 674-681 (1988).

11. Felder, R., and Soloman, B. (2006a). Index of Learning Styles. Retrieved on 2006 from web address: http://www.engr.ncsu.edu/learningstyles/ilsweb.html

12. Felder, R., and Soloman, B. (2006b).Learning Styles and Strategies. Retrieved on 2006 from web address: http://www2.ncsu.edu/unity/lockers/users/f/felder/public/ILSdir/styles.html

13. Freedman, R. D. \& Stumpf, R. D. 1980. Learning style theory: Less than meets the eye. Academy of Management Review. 5(3): 445-455

14. Grasha, A.F. 1994. A matter of style: The teacher as expert, formal authority, personal model, facilitator, and delegator. College Teaching. 42:142-149.

15. Grasha, A. F. 1996. Teaching with Style. Pittsburgh, PA: Alliance Publishers.

16. Grasha, A. F., \& Riechmann, R (2006). Teaching Style Survey. Retrieved on 2006 from web address: http://longleaf.net/teachingstyle.html 
17. Greiner, L.E., Bhambri, A., \& Cummings, T.G. 2003. Searching for a Strategy to Teach Strategy. Academy of Management Learning and Education, 2(4):402-420.

18. Hall, E., \& Moseley 2005. Is there a role for learning styles in personalized education and training? International Journal of Lifelong Education. 24(3):243-255.

19. Hanno, D. M. 1999. Energizing your teaching: Developing a community of learning. Issues in Accounting Education. 14(2): 323-336.

20. Hayes, J. \& Allinson, C. W. 2004. Cognitive style and its relevance for management practice. British Journal of Management. 5: 53-71.

21. Jung, C. G., Adler, G., and Hull R.F.C. (1976). Psychological Types (Collected Works of C. G. Jung Vol. 6). Bollingen Publishing.

22. Jenson, G. H. 1987. Learning styles: In Provost. J. A. and Anchors, S. (Eds). Application of the MyersBriggs type indicator in higher education (p. 181-206). Palo Alto, CA: Consulting Psychologists Press.

23. Kinman, G. \& Kinman, R. 2001. The role of motivation to learn in management education. Journal of Workplace Learning. 13(3/4):132-143.

24. Kolb, M. (1984). Experience as the source of learning and development. Englewood Cliffs: Prentice-Hall.

25. Kolb's Learning Style Inventory (2006). Learning Style Inventory Instrument. Retrieved on 2006 from web address: http://pss.uvm.edu/pss162/learning styles.html

26. Kolb, M., Boyatsis, R. E., and Mainemelis, C. (2001). Experiential learning theory: Previous Research and New Directions, in IL J. Sternberg and L. F. Zhang (eds), Perspectives on Thinking, Learning, and Cognitive Styles, pp. 247-47, Mahwah, NJ: Lawrence Erlbaum.

27. Laight, D. W. (2004). Attitudes to concept maps as a teaching/learning activity in undergraduate health professional education: Influence or preferred learning styles, Medical Teacher, 26 (3): 229-233

28. Lehto, B. A. 1989. A comparison of personalities and backgrounds of teachers using a whole language approach and basal approach in teaching elementary reading. DAI 51, 740A.

29. Loo, R. 2002. A meta-analytic examination of Kolb's learning style preferences among business majors. Journal of Education for Business. 77(5): 252-256.

30. Lyons, C. A. 1984. Consistency between learning style pattern and teaching style behaviors of prospective elementary teachers. ERIC Document Reproduction Service. No ED 244936.

31. McCombs, B. L. 1991. Motivation and lifelong learning. Educational Psychologist. 26(2): $117-127$.

32. Macfarlane, B., and Lomas, L. (1995). Client-based management education: Values and quality, Management Development and Review, 8 (1):32-37.

33. McMullan, W. \& Cahoon, A. 1979. Integrated abstract conceptualizing with experiential learning. Academy of Management Review. 4: 453-458.

34. Mumford, A. 1983. Emphasis on the Learner: A new approach. Leadership and Organizational Development Journal. 4(1): 17-20.

35. Mumford, A. \& Honey, P. 1992. Questions and answers on learning styles Questionnaire. Industrial and Commercial Training Guilsborough. 24(7): 10-14.

36. Mumford, A. 1995. Putting learning styles to work: An integrated approach. Industrial and Commercial Training Guilsborough. 27 (8): 28-36.

37. Quenk, N. L. (2000). Essentials of Myers-Briggs Type Indicator Assessment (Essentials of Psychological Assessment). Publisher: Wiley and Sons.

38. Randolph, W. \& Posner, B. 1979. Designing meaningful learning situations in management: A contingency decision-tree approach. Academy of Management Review. 4: 459-467.

39. Salaman, G. and Butler, J., Why managers won't learn, Management Education and Development, Vol. 23 No. 3, 1990, pp. 183-91.

40. Soloman, B. 1992. Inventory of Learning Styles. North Carolina State University, USA.

41. Spicer, D. P. (2004) The impact of approaches to learning and cognition on academic performance in business and management, Education and Training, 46 (4): 194-205.

42. Thompson, T. C. 1997. Learning styles and teaching styles: Who should adapt to whom? Business Communication Quarterly. 11(2): 501-503.

43. Turner, M. 1999. The learning experience. The British Journal of Administrative Management. 31(4-5): 12. 
44. Whetton, D. A., \& Clark, S. C. 1996. An integrative model for teaching and management skills. Journal of Management Education. 20(2): 152-181.

45. Wynd, W. R., \& Bozman, C. S. 1996. Student learning style: A segmentation strategy for higher education. Journal of Education for Business, 71(4): 232-246.

46. Van Zwanenberg, N, Wilkonson, L. J., and Anderson, A. (2000). Felder and Silverman's Index of Learning Styles and Honey and Mumford's Learning Styles Questionnaire: how do they compare and do they predict academic performance? Educational Psychology, 20 (3): 365-380.

47. Vroom, V. 1964; revised 1995. Work and Motivation. San Francisco: Jossey-Bass.

\section{$\underline{\text { NOTES }}$}


NOTES 